\title{
Significance of the two Atharvavedic Socio-political Institutions in the modern Indian political system
}

\author{
Dr. Urmimala Bora, \\ India.
}

\begin{abstract}
The Vedas contain the most valuable records of the Indo-Aryan society. These are also the most ancient documents we ever have. These Vedas are also known as Śruti, Candas, Trayi etc. There are four Vedas viz. the Rgveda, the Sämaveda, the Yajurveda and the Atharvaveda. In common parlance, these are the canonical books of Hindu religion. But a thorough, scientific and secular study gives knowledge of another aspect of these Vedas that these are not only the books of religion but are the origin of all sciences, arts and commerce and the result of a very high education system. Specially, the Rgveda and the Atharvaveda present a very clear picture of human life as well as social life. On this ground an attempt has been made to highlight the significance of the two Atharvavedic socio-political institutions in the modern Indian political system. The paper will also search some common needs of the ancient and modern people of India.
\end{abstract}

Key Words: Atharvaveda, sabhā, samiti, Rgveda, Lok Sabhā, Rājya Sabhā.

\section{Introduction}

In the Atharvaveda we come across two socio-political institutions related to governance and kingship viz. sabhā and samiti. The Atharvavedic society was ruled by a systematic government. The king was the supreme head of the country. He was selected by the king makers known as rājakrtah ${ }^{1}$. The group of the kingmakers consisted of the following persons:

i. dhīvānah the fishermen,

ii. rathakārāh the chariot-makers,

iii. karmārāh the black-smiths,

iv. manīṣinạa the intelligentsia,

v. rājānah the kings of other states or the people of royal families or the royal people.

vi. sūtāh i.e. those who lives as charioteers.

vii. grāmanyah the village headmen.

The verses which provide this information are as follows:

ye dhīvāno rathakārāḥ karmārāḥ ye manīṣiṇaḥ /

upastin parṇa mahyam tvam sarvān kṛ̣vobhito janān //

ye rājāno rājakṛtaḥ sūtāḥ grāmaṇyaśca ye /

upastin parṇa mahyam tvam sarvān kṛ̣vobhito janān // [Atharvaveda, III.5.6-7]

Thus it appears that these kingmakers were the representatives of the common people who themselves were probably selected as the members of the samiti by the common people. Kingship in Vedic times depended upon the acceptability of the king by the viśah i.e. the subject. An Atharvavedic passage ${ }^{2}$ which is also found in the Rgveda runs as follows -

Viśastvā sarvā vāňcantu mā tvadrāștramadhi bhraśt

[(O king), may all the people wish to have you (as a ruler). May the kingdom be not lost to you ]. ${ }^{3}$

The institutions of sabhā and samiti appear to have played vital roles in the proper running of a country. References to the sabhā and samiti are already found scattered in the Rgveda. The former was a gambling place and also a place for discussing topics relevant to the society. ${ }^{4}$ According to Sāyana the word samiti in the Rgveda simply means samhati i.e. a group and samgrāmạ̣ ${ }^{5}$ warfare. However, in Rgvedic examples like

\footnotetext{
${ }^{1} C f$., Sāyana, the commentator of the Aitareyabrāhmana,8.4.3 states that the räjakrtah means the relatives of the king. However, the fact that the king was selected by the people has been alluded to Rgveda, X.173.

${ }^{2} C f ., A V$, VI.87.1

${ }^{3}$ As translated by M. Bora

Cf., Concept of Monarchy and Governance In Atharvavedic India: A Note, Śabda-Sudhā (Golden Jubilee Celebration Research Journal) Dept. of Sanskrit, G.U.2007, p.104.

${ }^{4} C f$., $R V$., VI.28.6; X.34.6 etc.

${ }^{5} C f$., Sāyaṇa on $R V$. I.95.8;IX.92.6, X.11.8, 97.6, 166.6 etc. On I.95.8 Sāyaṇa explains the word as tejasāim samihati and on X.11.8 as stutisamihati.
} 
IX.92.6 and X.97.6 the word samiti appears to stand for an assembly which was regularly attended by the kings. Furthermore, in Rgveda X.191.3 the word has been used in all probability to mean a social gathering. The Atharvaveda refers to sabhā as a place of mirth and debate ${ }^{6}$. Thus in VII.12.2 it has been called narișțā: vidma te sabhe nāma narișțā nāma vā asi . It means, we know you o sabhā alias nariștāa Sāyaṇa interpreted the term nariștāa as inviolable (ahimsitā parairanabhi-bhāvyā) and the term sabhā as the council of scholars (vidușām samājah) ${ }^{\bar{\eta}}$. In this context, it is to be noted that it has been implied in an Atharvanic passage (III.19.1) that sabhā was associated with king and thus was more a political rather than a social institution. In this passage it has been stated that the members of the sabhā (sabhāsadaḥ) of Yama were rājānah and who shared the sixteenth part of the merit accruing from the good deeds of the people (yadrājāno vibhajanta istāpūrtasya șodasam yamasyāmisabhāsadah). Altekar, while referring to this Atharvavedic passage has observed that "It is possible to argue that the status of the members of the terrestrial sabhā like that of the celestial one was also almost the high as that of the king and that they too were entitled to receive a small share of the tithes and tributes that were paid to the ruler" ${ }^{\prime \prime}$. Alteker observed that the meaning of the sabhā and samiti differed from age to age and locality to locality ${ }^{9}$. As pointed out by Chakraborti the term sabhā has an Indo-European touch. He has shown that the word is derived from Indo-European s(u)e-bho and is closely associated with Old-European sib, German sippe, Old High German sipp(e)a and Gothic sibja - all meaning an association of kin (of tribe, family or clan) ${ }^{10}$. Scholars like Hillebrandt, Zimmer, Renou, Altekar, Ludwig, Majumdar, Jaiswal, Apte etc. have defined the word sabhā differently. Hillebrandt has even considered that the sabhā and samiti were one and same ${ }^{11}$. But there occurs an Atharvavedic passage which clearly mentions that the sabhā and samiti were two different bodies $^{12}$. William says that the word sabhā is of unknown derivation. Nevertheless he refers that sabhā stands for " an assembly, congregation, meeting, council, public audience" etc.

Another assembly i.e. the samiti was also a gathering of people. Williams states that the term samiti stands for "coming together, meeting, assembly, council ... encounter, hostile meeting, war, battle" etc. It may be stated here that Sāyana in his commentary on Atharvaveda, VII.12.1 has explained the meaning of the word samiti as samgrāmina janasabhā and thus he has suggested that samiti was an assembly of the people which was called in times of the war. The Atharvavedic passages seem to confirm that samiti was a political institute ${ }^{13}$. The regal power of a king depended upon his acceptability by the samiti. Thus it has been stated dhruvāya te samitih kalpatāmiha ${ }^{14}$. Thus it appears to have enjoyed the power to dethrone, to reinstate and also to restrain the king. It has been stated that the samiti does not support a king who transgresses the rights and privileges of a Brahmin : nāsmaih samitih kalpate na mitram nayate vaśam ${ }^{15}$

[ samiti does not think for this (king), friends (also) do not show respect to him]

Undoubtedly the members of the sabhā and samiti were required to be men of knowledge, wisdom and good personality ${ }^{16}$. Eloquence was indispensible for the members of the sabhā and samiti. One Atharvavedic passage (VII.12.2) it is stated that every man may respect and support the king at the meeting: yenā samgacchā upa mā sa śikṣāccāru vadāni pitarah samigateșu [ May every man I meet respect and aid me, Fair be my words, O fathers at the meetings.] ${ }^{17}$

The members of the sabhā and samiti required harmony and peace among themselves. Passages from the Atharvaveda and the Rgveda confirm this fact.

So far as the Indian polity is concerned, the council of people's representatives played the vital role regarding the supreme of the country i.e. the prime minister of India and government as the president of India played the role of a nominal head. In addition to this one would like to mention that the Indian Constitution offers parliamentary form of government to India. This parliament comprises the President of India, the Lok Sabha and the Rajya Sabha. The President is the nominal chief of the country. In fact, the government is controlled by the Prime-minister and the members of the council of ministers who are elected by the people of India. Similarly in ancient times, the Atharvan polity was somewhat federal where the king was the head of the state and the actual power was vested to the samiti as it is mentioned earlier. However, it is not clear that the members of samiti were selected or elected. There is no clear reference to the procedure of selection and the role of common people in selecting the members of samiti. Nevertheless the reference of common people in the same group of king, intelligentsia etc. leads to the fact that in that period common people also get equal place in

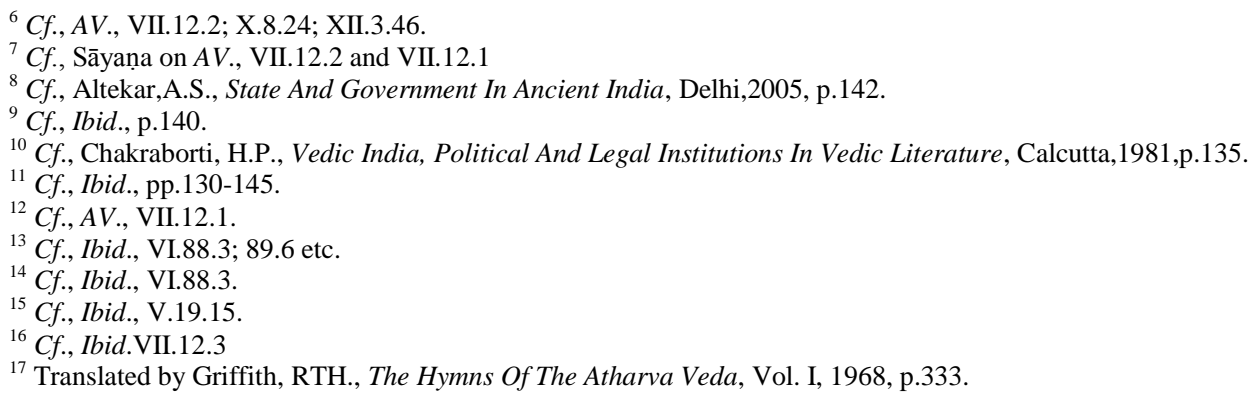


politics. But now in modern time in India there is no place for the common people. Although the constitution gives the power to cast vote in election in practice the voters are not so alert and in result India still after independence of sixty years is a country of class three. ${ }^{18}$ In this context one may mention that in modern Indian polity there occur so many problems. Of these, the most important one is the lake of unity among the members of the parliament. Many times it is seen that the members play the role of a taciturn man. Most of them also transgress the rules of morality and social virtue.

\section{Conclusion}

To conclude, one would like to state that definitely the idea of both Sabhas has been taken from the Vedic sabhā and samiti. Indeed the activities are different in many cases. In this juncture one would like to suggest that the members of the parliament should develop their personality and unity among them as the Vedic personals did. Many times it is noticed that the ministers tried to fulfil their personal needs. In this case ministers should learn morals from the Vedic people. Their aim should be to serve the nation at any rate. In fact these are the common needs from time to time in government.

\section{References:}

[1]. Atharvaveda (Śaunaka), vols. 1-4, with the pada-pātha and Sāyaṇācārya's commentary, ed. by, Vishva Bandhu, Vishveshvaranand Vedic Research Institute, Hoshiarpur,1960-89.

[2]. Rgveda-Samihitā, with the commentary of Sāyan̄ācārya, Pub. By, Vaidik Saminsodhan Maṇual, Poona, 1936.

[3]. $\quad$ Altekar,A.S., STATE AND GOVERMENT IN ANCIENT INDIA, Delhi, 1984.

[4]. Chakraborti, Hari Pada, VEDIC INDIA POLITICAL AND LEGAL INSTITUTIONS IN VEDIC LITERATURE, pub. By, Sanskrit Pustak Bhandar, Calcutta, 1981.

[5]. The Constitution of India, available at www. lawmin.nic.in.

${ }^{18}$ Information collected from the daily newspapers published from Assam and television channel of India in the year 2012 January- 2014 February. 